\title{
Is the best option of treatment being offered to patients with multiple coronary artery diseases?
}

\author{
Rui Manuel Sequeira de Almeida*
}

$\longrightarrow$

oronary arterial disease (CAD) is currently the most prevalent condition requiring cardiologist care. In spite of the progress in the clinical treatment of this disease over the last few years, there has been a change from clinical or surgical treatment to interventionist treatment, using several forms of angioplasty (PTA) [1]. To decide what is the best treatment method, it is necessary to considerer the strong evidence that single- and two-arterial CAD have similar outcomes, when comparing the clinical, interventionist and surgical treatments, but this is not true in relation to multiple vessel disease. Some facts must be discussed by patients suffering from multiple vessel diseases and a multidisciplinary team formed by a physician, hemodynamicist and surgeon so that a decision can be taken, not based on "cosmetology", but on proof based on medical evidence. With this in mind, the following aspects must be considered: a) the ischemia-free survival rate without re-interventions based on scientific works and b) the procedure cost over short, medium and long terms.

Databases have shown a reduction in the number of coronary artery bypass grafting surgeries (CABG) performed over the last few years with a drop of almost $20 \%$ comparing the total number of coronary artery surgeries performed in the USA in $1996(182,911)$ and in $2004(149,680)$ [2]. Simultaneously, the number of PTAs with or without the use of stents has increased almost geometrically [3].

In spite of having already observed a trend [4,5] in which PTAs have had an increase with subsequent reduction in the number of $\mathrm{CABG}$, in Brazil there has only been a rise in the number of PTAs with the number of CABG remaining stable [6]. The question is: is it possible that this increase is due to criteria based on evidence or simply a tendentious choice? Why are more and more patients with tri-arterial diseases referred for a less effective treatment at a greater cost?

CABG is the most studied surgical procedure in medical history and the results have been widely reported over the last 10 and 20 years [7]. The surgery has been successful in reducing ischemia and increasing the survival rate in most groups of patients with multiple vessel diseases. With the technical improvements and forms of myocardial protection, results have achieved hospital survival rates of $98 \%$. PTA, however, is a relatively new procedure with an enormous potential of change over the next few years but without an effective follow-up thus far. After its initiation using a balloon, PTA first developed with the use of plain stents and subsequently with drug-eluting stents, an evolution in which the devices presented with varying degrees of restenosis and early thrombosis [8].

To prove the "new" effectiveness of treatments with PTA, several studies have been performed, trying to demonstrate the superiority of this treatment in relation to the surgical treatment, with 6 performed with simple PTA (GABI [9], EAST [10], RITA [11], ERACI [12], CABRI [13], BARI [14]), five with the use of stents (MASS-2 [15], AWESOME [16], ERACI-2 [17], SoS [18], ARTS [19]) and another five with the use of drug-eluting stents (CARDia [20], SYNTAX [21], FREEDOM [22], COMBAT [23], Le MANS [24]).

However, the study groups used were low-risk groups in which CABG has little benefit and even so the surgical group included patients with "more severe" conditions, considering the number of arteries involved and the left ventricular function. Taggart [25], in his works, demonstrated two fundamental points; a) that the surgical treatment, in patients with lesions of one and two vessels who present with normal left ventricular function, does not increase the survival rate [26]; b) clinical trials comparing PTA and CABG, in spite of being, in the majority of cases, for single and two-lesion patients, present a greater re-intervention free survival rate for $\mathrm{CABG}$ and that groups in which surgery is recommended are not compared, including for multiple vessel disease and when the left ventricular function is compromised. This conclusion is evident in subgroups in which there is proximal involvement of the three main branches, in diabetic patients, when there is myocardial dysfunction and in those patients with injury to the left coronary arterial trunk [8,27]. Studies that compared CABG and PTA in patients with 
equivalent multiple arterial lesions [28], the event-free survival rate, including acute myocardial infarction, heart-related death and any type of revascularization, always favored surgical revascularization. This study reaffirms a previous study by the same group, MASS2 [15], in which on comparing both the event-free survival rate and the necessity of new interventions, the outcomes of the Surgical Group were better than the PTA Group and even the results of the Clinical Treatment Group were better than the PTA Group (Figures 1 and 2). In the same work, we can see the evolution of the three randomized groups over the first year, in which a statistical difference was demonstrated in respect to angina and the necessity of future $\mathrm{CABG}$ (Table 1).

We will not discuss here the biases of these works, which involved a group of patients of less than $5 \%$ of the original sample (of a series of 15 trails considering 8826 patients, only 441 were eligible to participate). When the results that portray the real world are analysed, the difference is more evident [29]. Taking into consideration the work by Yusuf et al. [26], for patients selected for comparative studies between

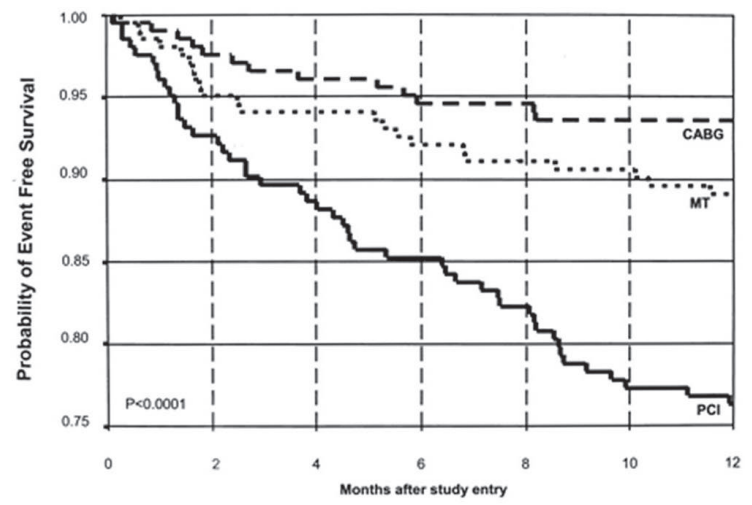

Fig. 1 - Event-free survival rate at one year, comparing $C A B G, P T A$ and clinical management. Figured taken from Hueb et al. [15]. Reproduced with the authorization of the Journal
CABG and PTA, there must be a great proportion of patients for which treatment with $\mathrm{CABG}$ is superior to clinical management.

Moreover, there is a necessity to review the concept of treatment in relation to its form [30]; while the approach to the disease in PTA is related to the "culprit lesion", in CABG it is related to the epicardial tissue of the artery. This fact added to the placement of a foreign body inside the lumen of the artery, contributes to high restenosis rates. An analysis of works that demonstrate the induction of a systemic inflammatory response on using coronary stents with restenosis as its first manifestation, contributes to the discussion on the physiopathology of this "new disease". Gomes et al. [31] demonstrated that, in spite of the introduction of covered stents having reduced intraluminal restenosis, the inflammatory response and restenosis at the edges remain. The same authors [32] affirm that CAD submitted to post-PTA CABG is a different disease to CABG without prior PTA and that the results may be different because of arteritis and, probably, associated myocarditis.

Another factor to be considered, when any type of

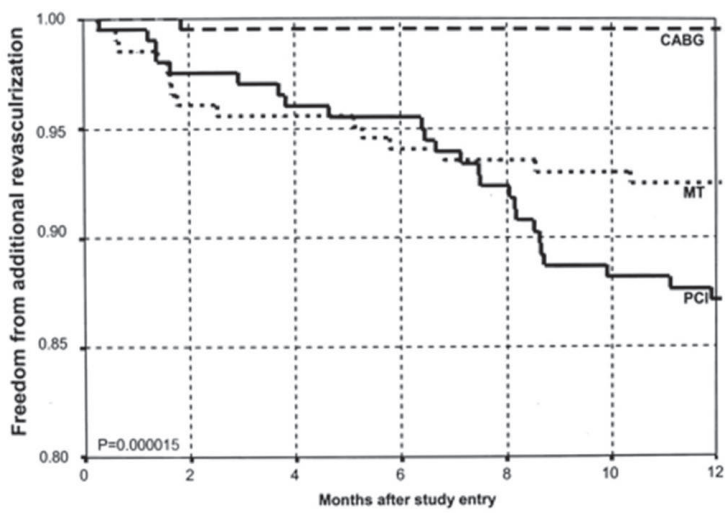

Fig. 2 -Re-intervention free survival rate at one year between CABG, PTA and clinical management. Figure taken from Hueb et al.[15]. Reproduced with the authorization of the Journal

Table 1. Evolution after a year of the three randomized groups.

\begin{tabular}{|c|c|c|c|c|}
\hline & CT $(n=203)$ & PTA $(n=205)$ & $\mathrm{CABG}(\mathrm{n}=203)$ & p-value \\
\hline$\overline{\text { Death }}$ & $3(1.5 \%)$ & $9(4.5 \%)$ & $8(4.0 \%)$ & 0.23 \\
\hline AMI with Q & $10(5.0 \%)$ & $16(8.3 \%)$ & $4(2.0 \%)$ & 0.01 \\
\hline II or III (CCS) Functional Class & $126(63.6)$ & $87(45.3 \%)$ & $75(39 \%)$ & $<0.0001$ \\
\hline Stroke & $3(1.5 \%)$ & $2(1.0 \%)$ & $3(1.5 \%)$ & 0.29 \\
\hline CABG & $12(6.0 \%)$ & $7(3.5 \%)$ & - & $<0.0001$ \\
\hline PTA & $4(1.97 \%)$ & $18(8.78 \%)$ & $1(0.5 \%)$ & 0.008 \\
\hline
\end{tabular}

CCS - Canadian Cardiovascular Society. AMI - acute myocardial infarct. CT-clinical treatment PTA - Angioplasty. CABG - Coronary artery bypass grafting. Table taken from Hueb et al.[15]. Reproduced with the authorization of the Journal 
treatment is analysed, is the cost mainly in a country such as Brazil, in which $75 \%$ of patients are cared for by the government healthcare system. Previous works demonstrated that in spite of the initial cost being higher in CABG, after a year of follow-up, the PTA group becomes more expensive, not only because of the number of re-interventions, but also for the use of drug-eluting stents [33- 35]. When the costs to the government healthcare system per patient for all types of PTAs and CABGs are taken in consideration, it can be seen that the cost of PTAs is $75 \%$ greater than CABG only with hospitalizations [4]. With this, it can be seen that in the USA, the use of the covered stents is $80 \%$ of the total [36], giving higher costs to the healthcare system, so that Medicare had to reduce its payments to reference centers by a third thereby reducing the quotas for companies that produce covered stents [37].

With all these data, it is difficult to understand, why the best treatment [1] for the lowest cost is not offered to patients.

*Associate Professor of Cardiology and Cardiovascular Surgery of Universida Estadual do Oeste do Paraná. Member of the Editorial Board of BJCVS

\section{REFERENCES}

1. Opie LH, Commerford PJ, Gersh BJ. Controversies in stable coronary artery disease. Lancet. 2006;367(9504):6978 .

2. The Society of Thoracic Surgeons. STS Adult CV Surgery National Database - Fall 2005 Executive Summary Contents. Available from: http://www.sts. org/documents /pdf/STS-ExecutiveSummaryFall2005. pdf

3. British Cardiovascular Intervention Society - BCIS Audit. Available from: http://www.bcis.org.uk/resources/ audit

4. Mack MJ, Brown PP, Kugelmass AD, Battaglia SL, Tarkington LG, Simon AW et al. Current status and outcomes of coronary revascularization 1994 to 2002: 148,396 surgical and percutaneous procedures. Ann Thorac Surg. 2004;77(3):761-8.

5. The Society of Cardiovascular Surgeons of Great Britain and Ireland - UK Cardiac Surgical Register. Available from: http://www.scts.org/index.cfm?ukcardiacreg=yes
6. Ministério da Saúde Brasileiro. Datasus - Informações de Saúde - Rede Assistencial - Rede Hospitalar do SUS - Brasil. Available from: http://tabnet.datasus.gov. $\mathrm{br} / \mathrm{cgi} / \mathrm{deftohtm}$.exe?sih/ cnv/cxuf.def

7. Reul RM. Will drug-eluting stents replace coronary artery bypass surgery? Tex Heart Inst J. 2005;32(3):32330.

8. Serruys PW, Kutryk MJ, Ong AT. Coronary-artery stents. N Engl J Med. 2006;354(5):483-95.

9. Hamm CW, Reimers J, Ischinger T, Rupprecht HJ, Berger J, Bleifeld W. A randomized study of coronary angioplasty compared with bypass surgery in patients with symptomatic multivessel coronary disease. German Angioplasty Bypass Surgery Investigation (GABI). N Engl J Med. 1994;331(16):1037-43.

10. King SB 3rd, Lembo NJ, Weintraub WS, Kosinski AS, Barnhart HX, Kutner MH et al. A randomized trial comparing coronary angioplasty with coronary bypass surgery. Emory Angioplasty versus Surgery Trial (EAST). N Engl J Med. 1994;331(16):1044-50.

11. Pocock SJ, Henderson RA, Seed P, Treasure T, Hampton JR. Quality of life, employment status, and anginal symptoms after coronary angioplasty or bypass surgery. 3-year follow-up in the Randomized Intervention Treatment of Angina (RITA) Trial. Circulation. 1996;94(2):135-42.

12. Rodriguez A, Boullon F, Perez-Balino N, Paviotti C, Liprandi MI, Palacios IF. Argentine randomized trial of percutaneous transluminal coronary angioplasty versus coronary artery bypass surgery in multivessel disease (ERACI): in-hospital results and 1-year follow-up. ERACI Group. J Am Coll Cardiol. 1993;22(4):1060-7.

13. CABRI Trial Participants. First-year results of CABRI (Coronary Angioplasty versus Bypass Revascularisation Investigation). Lancet. 1995;346(8984):1179-84.

14. Feit F, Brooks MM, Sopko G, Keller NM, Rosen A, Krone $\mathrm{R}$ et al. Long-term clinical outcome in the Bypass Angioplasty Revascularization Investigation Registry: comparison with the randomized trial. BARI Investigators. Circulation. 2000;101(24):2795-802.

15. Hueb W, Soares PR, Gersh BJ, Cesar LA, Luz PL, Puig LB et al. The medicine, angioplasty, or surgery study (MASS-II): a randomized, controlled clinical trial of three therapeutic strategies for multivessel coronary artery disease: one-year results. J Am Coll Cardiol. 2004;43(10):1743-51.

16. Sedlis SP, Morrison DA, Lorin JD, Esposito R, Sethi G, Sacks J et al. Percutaneous coronary intervention versus 
coronary bypass graft surgery for diabetic patients with unstable angina and risk factors for adverse outcomes with bypass: outcome of diabetic patients in the AWESOME randomized trial and registry. J Am Coll Cardiol. 2002;40(9):1555-66.

17. Rodriguez A, Rodriguez Alemparte M, Baldi J, Navia J, Delacasa A, Vogel D et al. Coronary stenting versus coronary bypass surgery in patients with multiple vessel disease and significant proximal LAD stenosis: results from the ERACI II study. Heart. 2003;89(2):184-8.

18. SoS Investigators. Coronary artery bypass surgery versus percutaneous coronary intervention with stent implantation in patients with multivessel coronary artery disease (the Stent or Surgery trial): a randomised controlled trial. Lancet. 2002;360(9338):965-70.

19. Abizaid A, Costa MA, Centemero M, Abizaid AS, Legrand VM, Limet RV et al. Clinical and economic impact of diabetes mellitus on percutaneous and surgical treatment of multivessel coronary disease patients: insights from the Arterial Revascularization Therapy Study (ARTS) trial. Circulation. 2001;104(5):533-8.

20. Kapur A, Malik IS, Bagger JP, Anderson JR, Kooner JS, Thomas $\mathrm{M}$ et al. The Coronary Artery Revascularisation in Diabetes (CARDia) trial: background, aims, and design. Am Heart J. 2005;149(1):13-9.

21. Kappetein AP, Dawkins KD, Mohr FW, Morice MC, Mack MJ, Russell ME et al. Current percutaneous coronary intervention and coronary artery bypass grafting practices for three-vessel and left main coronary artery disease. Insights from the SYNTAX run-in phase. Eur J Cardiothorac Surg. 2006;29(4):486-91.

22. Serruys PW, Kutryk MJ, Ong AT. Coronary-artery stents. N Engl J Med. 2006 Feb 2;354(5):483-95.

23. The Heart.org. Heartwire. Available from: http://www. theheart.org/article/399487.do

24. The Heart.org. Heartwire. Available from: http://www. theheart.org/article/581205.do

25. Taggart DP. Surgery is the best intervention for severe coronary artery disease. BMJ. 2005;330(7494):785-6.

26. Yusuf S, Zucker D, Peduzzi P, Fisher LD, Takaro T, Kennedy JW et al. Effect of coronary artery bypass graft surgery on survival: overview of 10 -year results from randomised trials by the Coronary Artery
Bypass Graft Surgery Trialists Collaboration. Lancet. 1994;344(8922):563-70.

27. Klein LW. Are drug-eluting stents preferred treatment for multivessel coronary artery disease? J Am Coll Cardiol. 2006;47(1):22-6.

28. Silva PR, Hueb WA, Cesar LA, Oliveira SA, Ramires JA. Estudo comparativo dos resultados da intervenção cirúrgica e da angioplastia na revascularização do miocárdio em portadores de comprometimento multiarterial equivalente. Arq Bras Cardiol. 2005;84(3):214-21.

29. Hannan EL, Racz MJ, Walford G, Jones RH, Ryan TJ, Bennett $\mathrm{E}$ et al. Long-term outcomes of coronary-artery bypass grafting versus stent implantation. $\mathrm{N}$ Engl J Med. 2005;352(21):2174-83.

30. Gersh BJ, Frye RL. Methods of coronary revascularization: things may not be as they seem. N Engl J Med. 2005;352(21):2235-7.

31. Gomes WJ, Giannotti-Filho O, Hossne NA Jr, Catani R, Buffolo E. Inflammatory reaction after sirolimus-eluting stent implant. Ann Thorac Surg. 2005;80(5):1903-4.

32. Gomes WJ, Giannotti-Filho O, Catani R, Paez, Hossne NA Jr RP, Buffolo E. Coronary artery and myocardial inflammatory reaction induced by intracoronary stent. Rev Bras Cir Cardiovasc 2002;17(4):293-8.

33. Almeida RMS. Revascularização do miocárdio: estudo comparativo do custo da cirurgia convencional e da angioplastia transluminal percutânea. Rev Bras Cir Cardiovasc. 2005;20(2):142-8.

34 Nagle PC, Smith AW. Review of recent US cost estimates of revascularization. Am J Manag Care. 2004;10(11 Suppl):S370-6.

35. Hill R, Bagust A, Bakhai A, Dickson R, Dundar Y, Haycox A et al. Coronary artery stents: a rapid systematic review and economic evaluation. Health Technol Assess. 2004;8(35):iii-iv, 1-242.

36. Gruchalla KJ, Nawarskas JJ. The paclitaxel-eluting stent in percutaneous coronary intervention: part I: background and clinical comparison to bare metal stents. Cardiol Rev. 2006;14(2):88-98.

37. The Heart.org. Heartwire. Available from: http://www. theheart.org/viewArticle.do?primary Key $=687991 \& n 1$ id=tho 18 apr06 